\title{
LENGTH-WEIGHT RELATIONS FOR SEVEN GRENADIER SPECIES (ACTINOPTERYGII: GADIFORMES: MACROURIDAE) TO THE WEST OF IRELAND
}

\author{
Brendan O’HEA*, Graham JOHNSTON, Jonathan WHITE, and Leonie DRANSFELD \\ Marine Institute, Rinville, Oranmore, Co. Galway, Ireland
}

\begin{abstract}
O’Hea B., Johnston G., White J., Dransfeld L. 2013. Length-weight relations for seven grenadier species (Actinopterygii: Gadiformes: Macrouridae) to the west of Ireland. Acta Ichthyol. Piscat. 43 (4): 285-291.

Abstract. Length-weight regressions for seven grenadier species: Coryphaenoides rupestris Gunnerus, 1765, Trachyrincus murrayi Günther, 1887, Coelorinchus caelorhincus (Risso, 1810), Nezumia aequalis (Günther, 1878), Coryphaenoides mediterraneus (Giglioli, 1893), Coelorinchus labiatus (Köhler, 1896), and Coryphaenoides guentheri (Vaillant, 1888) are calculated from data collected on a series of deepwater surveys conducted by the Irish Marine Institute from 2006 to 2009 , on the continental slope to the west and northwest of Ireland and the northern slope of the Porcupine Bank. The regression calculated for roundnose grenadier, C. rupestris, is compared with other regressions calculated for the species from different areas of its north Atlantic range. The difficulties associated with measuring many grenadier species, due to the fragility of their tails, are discussed. A recommendation is made that pre-anal fin length should be accepted as the standard.
\end{abstract}

Keywords: rattails, whiptails, deepwater survey, length-weight regression, northeast Atlantic, pre-anal fin length, regression comparison

Grenadiers have a short, squat body, which leads into a long whip-like tail. In many species the tail is very fragile and can break easily. This creates difficulties when measuring samples. Grenadier length measurements have been the subject of research since the 1960s. Much of this work however has tended to focus on roundnose grenadier, Coryphaenoides rupestris Gunnerus, 1765, and roughhead grenadier, Macrourus berglax Lacepède, 1801 (see Jørgensen 1996, Kelly et al. 1997, Danke 1987, Magnusson 1987, Atkinson 1981, 1991, Savvatimsky 1994).

Over the years, different length measurements have been used in different countries and for different Macrouridae species: total length (TL; Gordon 1978), head length (HL; measured from the tip of the snout to the posterior end of the operculum; Coggan et al. 1999, Swan et al. 2003), pre-anus length (PA; from the tip of the snout to the front edge of the anus; Bergstad 1990, Kelly et al. 1997), and pre-anal fin length (PAFL; from the tip of the snout to the base of the first anal fin ray (Jørgensen 1996) (Fig. 1). The lengths were rounded to the nearest $0.5 \mathrm{~cm}$. In the cited sources, lengths have been measured either in whole centimetres, half centimetres, or millimetres.

In this study data from the Irish deepwater surveys 2006 to 2009 are used to derive length-weight relations for 7 species of grenadier caught to the west of Ireland. It also compares length-weight relations for Coryphaenoides rupestris from this work with other regressions derived for different areas of the North Atlantic, and determines if any differences in length by location can be observed. Data used in these regressions were collected at different times during the year. Where authors produced a number of regressions we selected the one corresponding closest to our work. Length-weight relations are compared with Greenlandic data for Günther's grenadier, Coryphaenoides guentheri (Vaillant, 1888), as is pre-anal fin length to total length data for Murray's grenadier, Trachyrincus murrayi (Günther, 1887).

The Irish Marine Institute conducted a series of deepwater fishing surveys aboard the $R / V$ Celtic Explorer between 2006 and 2009, (ICES survey codes IDWS2006-2009). From 2006 to 2008 the surveys were carried out in September, but moved to December in 2009. The surveys concentrated on three areas of the continental slope to the west of Scotland and Ireland, and the northern slope of the Porcupine Bank (Fig. 2). These areas are a subset of areas fished during a series of deepwater surveys carried out by the Institute in the 1990s. Survey methodology and sample collection protocols were based on those developed by the International Bottom Trawl Survey (Anonymous 2012), and followed measurement protocols used by the Scottish Marine Laboratory which were subsequently adopted by the Planning Group

\footnotetext{
${ }^{*}$ Correspondence: Mr Brendan O’Hea, Fisheries Ecosystems Advisory Services, Marine Institute, Rinville, Oranmore, Co. Galway, Ireland, phone: +353 91 387200, fax: +35391387201, e-mail: brendan.ohea@marine.ie.
} 
on North-East Atlantic Continental Slope Survey, PGNEACS (Anonymous 2008). Fishing hauls were made at depths of 500, 750,1000, 1500, and $1800 \mathrm{~m}$ in each area. Fishing tows were carried out along the contour of the slope. Effective fishing time, from when the net settled on the bottom to when it was hauled, was $2 \mathrm{~h}$ from 2006 to 2008. In 2009, based on the recommendation of PGNEACS it was decided to reduce the fishing time to $1 \mathrm{~h}$ (Anonymous 2009). Net and gear specifications can be found in Anonymous 2008.

Fish catches were fully sorted, normally to species level, and weighed. Each year full biological sampling, i.e., length, weight, sex, maturity, and otolith collection was carried out on a number of target commercial species, including Coryphaenoides rupestris. For species where a large catch was made during a haul a random sub-sample of that catch was taken for length and weight measurements. Length measurements were carried out on all other grenadier species. All grenadiers were measured from the tip of the snout to the pre-anal fin, measurements are rounded to the nearest half centimetre below. The fish being measured are rounded to the measurement below their length (a grenadier of $5.9 \mathrm{~cm}$ would be recorded as $5.5 \mathrm{~cm}$ rather than $6.0 \mathrm{~cm}$ ). Total weights were to the nearest gram. Length and weight data on some grenadier species were collected on an opportunistic basis, whenever time allowed.

Random samples were also frozen for later measurements in the laboratory. For these samples length meas- urements of pre-anus length and pre-anal fin length were made to the nearest millimetre below, and weight to the nearest $0.1 \mathrm{~g}$. For two species with robust, unbroken, tails, Coelorinchus caelorhincus (Risso, 1810), and Trachyrincus murrayi, measurements of total length were also carried out.

Linear regressions were carried out to derive a relation for pre-anal fin lengths to total lengths,

$$
y=a+b x
$$

where: $y=$ TL $[\mathrm{cm}], x=$ PAFL $[\mathrm{cm}], b=$ slope, and $a=$ intercept. For lengths and weights regressions in the form $W=a L^{b}$

were: derived where $W=$ weight $[\mathrm{g}], L=$ PAFL [cm], $b=$ slope, and $a=$ intercept (Tables 1 and 2). Outliers in the data were identified on the log transformed data by calculating the distance measure "DFFITS", which establishes the predictive value of each data point by recalculating the regression with each point omitted in relation to the original regression function (Belsley et al. 1980). By comparing against a critical value defined as $\sqrt[2]{\mathrm{p} / \mathrm{n}}$ where $p$ is the number of parameters in the model and $n$ is the number of observations, outliers can be objectively identified and removed.

These outliers were then extracted from the dataset and the length weight relations were recalculated. Froese (2006) and Froese et al. (2011) recommend that the 95\% confidence limits of the slope $b$, and the intercept $a$, as well as the sample size $(n)$ should be reported. These results are presented in Table 3.

Table 1

Length-weight relations for seven grenadier species (Actinopterygii: Macrouridae), including previously published data

\begin{tabular}{|c|c|c|c|c|c|}
\hline \multirow{2}{*}{ Species } & \multicolumn{2}{|c|}{$L-W$ parameters } & \multirow{2}{*}{$r^{2}$} & \multirow{2}{*}{$L-W$ relation } & \multirow{2}{*}{ Area [reference] } \\
\hline & $a$ & $b$ & & & \\
\hline Coryphaenoides rupestris & 0.478 & 2.687 & 0.988 & PAFL- $W$ & Greenland $[\mathrm{J}]$ \\
\hline Coryphaenoides rupestris [ㅇ] & 0.239 & 2.872 & 0.991 & PAFL- $W$ & Mid-Atlantic Ridge [D] \\
\hline Coryphaenoides rupestris $[\widehat{\jmath}]$ & 0.198 & 2.958 & 0.991 & PAFL- $W$ & Mid-Atlantic Ridge [D] \\
\hline Coryphaenoides rupestris & 0.732 & 2.587 & & $\mathrm{PA}-W$ & Rockall Trough $[\mathrm{K}]$ \\
\hline Coryphaenoides rupestris & 0.48 & 2.63 & & $\mathrm{PA}-W$ & Skagerrak [B] \\
\hline Coryphaenoides rupestris & 0.213 & 2.944 & 0.976 & PAFL $-W$ & Rockall Trough [O'] \\
\hline Coryphaenoides rupestris & 0.388 & 2.877 & & PAFL $-W$ & Iceland $[\mathrm{M}]$ \\
\hline Coryphaenoides guentheri & 0.278 & 2.705 & 0.997 & PAFL $-W$ & Greenland $[\mathrm{J}]$ \\
\hline Coryphaenoides guentheri & 0.227 & 2.644 & 0.931 & PAFL $-W$ & Rockall Trough [O’] \\
\hline Trachyrincus murrayi & 0.132 & 2.583 & 0.824 & PAFL $-W$ & Rockall Trough [O’] \\
\hline Coelorinchus caelorhincus & 0.51 & 2.385 & 0.91 & PAFL- $W$ & Rockall Trough [O’] \\
\hline Coelorinchus caelorhincus & 0.001 & 2.42 & 0.87 & PAFL- $W$ & Ionian Sea [L] \\
\hline Nezumia aequalis (fresh) & 0.251 & 2.786 & 0.901 & PAFL- $W$ & Rockall Trough [O’] \\
\hline Nezumia aequalis (frozen) & 0.367 & 2.646 & 0.761 & PAFL $-W$ & Rockall Trough [O’] \\
\hline Coryphaenoides mediterraneus & 0.25 & 2.832 & 0.986 & PAFL- $W$ & Rockall Trough [O’] \\
\hline Coelorinchus labiatus & 0.072 & 2.873 & 0.969 & PAFL- $W$ & Rockall Trough [O’] \\
\hline
\end{tabular}

$L=$ length (generalized), $W=$ weight, $a=$ slope, $b=$ intercept, $r^{2}=$ coefficient of determination; PA = pre-anus length, PAFL = pre-anal fin length; References: J = Jørgensen (1996), D = Danke (1987), K = Kelly et al. (1997), B = Bergstad (1990), O’ = this study, $\mathrm{M}=$ Magnusson (1987), $\mathrm{L}=$ Labropoulou and Papaconstantinou (2000). 
In total 91835 grenadiers comprising ten species were caught over the time series. Length-weight relations were calculated for seven grenadier species (Table 1). In addition PAFL to TL relations were calculated for the two species with robust tails, Trachyrincus murrayi and Coelorinchus caelorhincus (Table 2). A comparison of length-weight relations of Coryphaenoides rupestris from different regions of the Northeast Atlantic will be shown.

Attempts were made to develop PAFL to TL conversion factors for a number of species. In many of the species studied however, the fragility of the tail was a major problem. It proved difficult to find fish with fully intact tails. This was despite the fact that the fish brought back to the laboratory were selected specifically as having complete tails. For $C$. rupestris, an intact fish was defined as one where the tail terminated at a hair-like point. Only 5 such fish were found in a pre-selected sample of 130 'intact' fish, illustrating the difficulty in measuring total length in grenadier species. Bajdalinov et al. (1986) note that $C$. rupestris with unbroken, or slightly broken, caudal peduncles belong mainly to younger age classes. The number of fish with damage increases with increasing length, and unbroken tails are rarely found on larger fish.

Linear regressions derived for major length relations

Table 2 of four grenadier species (Actinopterygii: Macrouridae), including previously published data

\begin{tabular}{|c|c|c|c|c|c|c|c|c|}
\hline \multirow{2}{*}{ Species } & \multicolumn{2}{|c|}{$L-W$ parameters } & \multirow{2}{*}{$r^{2}$} & \multirow{2}{*}{ Length relation } & \multirow{2}{*}{$n$} & \multicolumn{2}{|c|}{ PAFL $[\mathrm{cm}]$} & \multirow{2}{*}{-Area [reference] } \\
\hline & $a$ & $b$ & & & & Min & Max & \\
\hline \multirow{2}{*}{ Coryphaenoides rupestris } & 0.175 & 0.912 & 0.99 & PA-PAFL & 131 & 2 & 26 & Rockall Trough [O'] \\
\hline & 0.036 & 0.941 & 0.994 & PA-PAFL & 8565 & 5 & 21 & Greenland [A] \\
\hline \multirow[t]{2}{*}{ Coryphaenoides guentheri } & 2.378 & 3.246 & 0.93 & PAFL-Tl & 752 & 3 & 13 & Greenland $[\mathrm{J}]$ \\
\hline & 9.469 & 1.791 & 0.87 & PAFL-TL & 111 & 11.9 & 19.1 & Rockall Trough [O'] \\
\hline \multirow[t]{2}{*}{ Trachyrincus murrayi } & 4.726 & 3.452 & 0.82 & PAFL-TL & 30 & 3.8 & 7.7 & Rockall Trough [O'] \\
\hline & 3.985 & 2.238 & 0.98 & PAFL-TL & 122 & 7 & 25 & Greenland $[\mathrm{J}]$ \\
\hline \multirow{2}{*}{ Coelorinchus caelorhincus } & 7.01 & 2.369 & 0.887 & PAFL-TL & 31 & 7.8 & 14.1 & Rockall Trough [O’] \\
\hline & -7.84 & 0.33 & 0.97 & PAFL-TL & & 11 & 27 & Gulf of Cadiz [G] \\
\hline
\end{tabular}

$L=$ length (generalized), $W=$ weight, $a=$ slope, $b=$ intercept, $r^{2}=$ coefficient of determination, $n=$ number of fish, $\mathrm{PAFL}=$ pre-anal fin length, $\mathrm{PA}=$ pre-anus length, $\mathrm{TL}=$ total length; References: $\mathrm{O}^{\prime}=$ this study, $\mathrm{A}=$ Atkinson $(1981)$ $\mathrm{J}=$ Jørgensen (1996), $\mathrm{G}=$ Gil et al. (2008).

Table 3

Log-transformed values of length-weight relation data for seven grenadier species (Actinopterygii: Macrouridae)

\begin{tabular}{|c|c|c|c|c|c|c|c|c|c|c|c|c|c|}
\hline \multirow[t]{2}{*}{ Species } & \multirow{2}{*}{\multicolumn{2}{|c|}{$\begin{array}{c}\text { Relation } \\
\text { (measurement) }\end{array}$}} & \multicolumn{2}{|c|}{$\begin{array}{c}L-W \\
\text { parameters }\end{array}$} & \multirow[t]{2}{*}{$r^{2}$} & \multirow[t]{2}{*}{$n$} & \multirow[t]{2}{*}{$P$} & \multirow{2}{*}{$\begin{array}{l} \pm 95 \% \\
\operatorname{cl} a\end{array}$} & \multirow{2}{*}{$\begin{array}{l} \pm 95 \% \\
\operatorname{cl} b\end{array}$} & \multicolumn{2}{|c|}{$\begin{array}{l}\text { PAFL } \\
{[\mathrm{cm}]}\end{array}$} & \multicolumn{2}{|c|}{$\begin{array}{c}\text { Weight } \\
{[\mathrm{g}]}\end{array}$} \\
\hline & & & $a$ & $b$ & & & & & & Min & Max & Min & Max \\
\hline $\begin{array}{l}\text { Coryphaenoides } \\
\text { rupestris }\end{array}$ & PAFL- $W$ & $\begin{array}{c}\log \\
\text { Anti-log }\end{array}$ & $\begin{array}{r}-0.67 \\
0.214\end{array}$ & $\begin{array}{l}2.943 \\
876.3\end{array}$ & 0.981 & 1661 & $<0001$ & 0.011 & $\begin{array}{l}0.02 \\
40.7\end{array}$ & 2 & 26 & 2 & 2884 \\
\hline $\begin{array}{l}\text { Coryphaenoides } \\
\text { guentheri }\end{array}$ & PAFL- $W$ & $\begin{array}{c}\log \\
\text { Anti-log }\end{array}$ & $\begin{array}{r}-0.536 \\
0.291\end{array}$ & $\begin{array}{l}2.547 \\
352.4\end{array}$ & 0.942 & 69 & $<0001$ & $\begin{array}{l}0.156 \\
0.125\end{array}$ & $\begin{array}{l}0.154 \\
149.9\end{array}$ & 4.5 & 15 & 14 & 312 \\
\hline $\begin{array}{l}\text { Trachyrincus } \\
\text { murrayi }\end{array}$ & PAFL- $W$ & $\begin{array}{c}\log \\
\text { Anti-log }\end{array}$ & $\begin{array}{c}-0.843 \\
0.14\end{array}$ & $\begin{array}{l}2.554 \\
357.7\end{array}$ & 0.842 & 106 & $<0001$ & $\begin{array}{l}0.257 \\
1.808\end{array}$ & $\begin{array}{l}0.215 \\
1.642\end{array}$ & 11.9 & 19.1 & 83.5 & 265. \\
\hline Nezum & PAFL- $W$ & $\begin{array}{c}\log \\
\text { Anti-log }\end{array}$ & $\begin{array}{c}-0.51 \\
0.309\end{array}$ & $\begin{array}{l}2.728 \\
534.5\end{array}$ & 0.834 & 207 & $<0001$ & $\begin{array}{l}0.131 \\
0.109\end{array}$ & $\begin{array}{l}0.167 \\
251.4\end{array}$ & 4.4 & 8 & 18.2 & 85 \\
\hline $\begin{array}{l}\text { Coryphaenoides } \\
\text { mediterraneus }\end{array}$ & PAFL- $W$ & $\begin{array}{c}\log \\
\text { Anti-log }\end{array}$ & $\begin{array}{r}-0.612 \\
0.244\end{array}$ & $\begin{array}{r}2.84 \\
691.5\end{array}$ & 0.993 & 41 & $<0001$ & $\begin{array}{l}0.08 \\
0.05\end{array}$ & $\begin{array}{l}0.076 \\
133.1\end{array}$ & 4.5 & 21.5 & 14 & 1522 \\
\hline $\begin{array}{l}\text { Coelorinchus } \\
\text { labiatus }\end{array}$ & PAFL- $W$ & $\begin{array}{c}\log \\
\text { Anti-log }\end{array}$ & $\begin{array}{r}-1.194 \\
0.064\end{array}$ & $\begin{array}{l}2.918 \\
827.1\end{array}$ & 0.935 & 67 & $<0001$ & $\begin{array}{l}0.195 \\
0.036\end{array}$ & $\begin{array}{l}0.19 \\
454.9\end{array}$ & 7.5 & 19.5 & 22 & 355 \\
\hline $\begin{array}{l}\text { Coelorinchus } \\
\text { caelorhincus }\end{array}$ & PAFL- $W$ & $\begin{array}{c}\log \\
\text { Anti-log }\end{array}$ & $\begin{array}{l}0.706 \\
5.08\end{array}$ & $\begin{array}{l}1.345 \\
22.13\end{array}$ & 0.636 & 93 & $<0001$ & $\begin{array}{l}0.236 \\
3.671\end{array}$ & $\begin{array}{l}0.212 \\
13.9\end{array}$ & 8 & 14.5 & 76 & 322 \\
\hline
\end{tabular}

$L=$ length (generalized), $W=$ weight, $a=$ slope, $b=$ intercept, $r^{2}=$ coefficient of determination, PAFL = pre-anal fin length, $\mathrm{PA}=$ pre-anus length, $\mathrm{TL}=$ total length; $\pm 95 \% \mathrm{cl}=$ confidence limits (of $a$ and $b$ ); Outliers were removed from the datasets according to DFFITS (Belsley et al. 1980); $n=$ number of specimens utilised after outliers were discarded; $P=P$ value. 


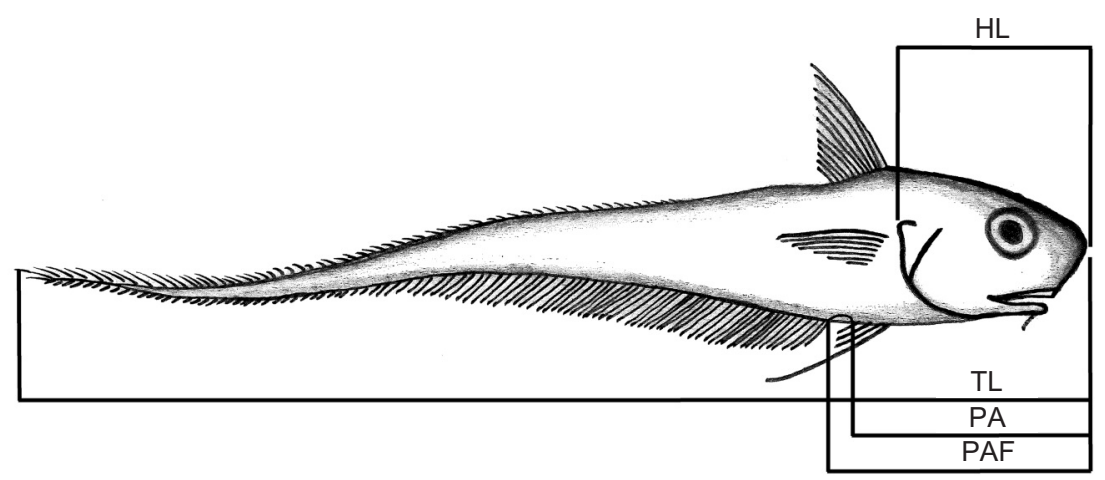

Fig. 1. A diagram showing the various length measurements in use for grenadiers (Actinopterygii: Macrouridae); $\mathrm{HL}=$ head length, $\mathrm{TL}=$ total length, $\mathrm{PA}=$ pre-anus length and $\mathrm{PAFL}=$ pre-anal fin length

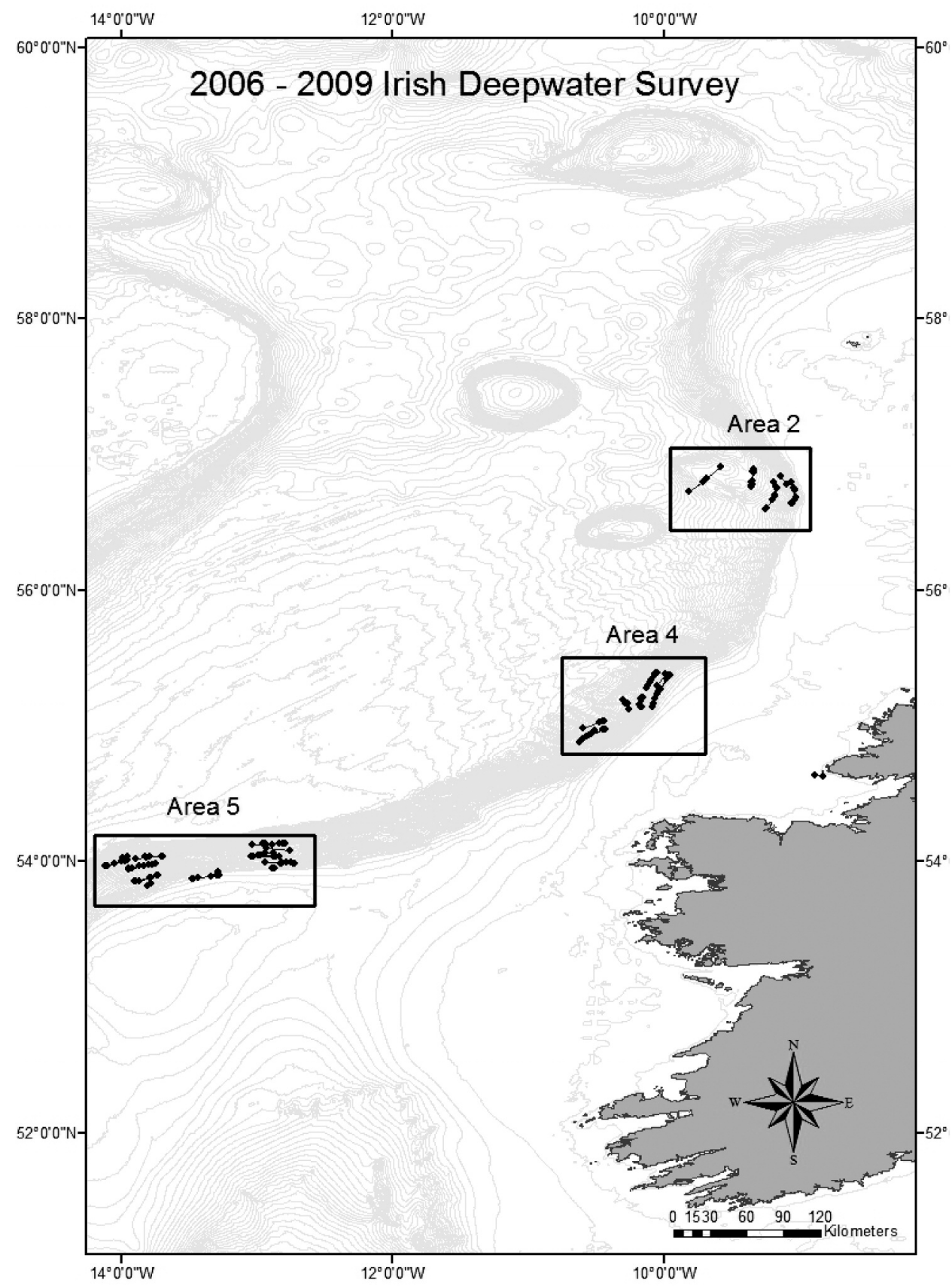

Fig. 2. Fishing tows and Areas fished during the Irish Deepwater surveys 2006-2009; The map was created by the Marine Institute using ArcMap 10 and the projection used is WGS84 


\section{Coryphaenoides rupestris Gunnerus, 1765}

In total, 53220 C. rupestris were caught on survey. Length and weight measurements were taken from 1756 fish, of which 813 were female, 746 were male, and 197 were unsexed. The unsexed fish tended to be small and difficult to assess. The mean size and weight of the females was larger than the males.

Comparison studies were carried out with a number of other length-weight relations derived from other areas of the North Atlantic: west Greenland (Jørgensen 1996), on the mid-Atlantic ridge (Danke 1987), in the Skagerrak (Bergstad 1990), in Icelandic waters (Magnusson (1987), and in the Rockall Trough (Kelly et al 1997) (Fig. 3). A number of published relations are not presented in this document (e.g., Gordon 1978, Coggan et al. 1999, Swan et al. 2003) as the fish were measured to either TL or HL, for which we have no conversion factors. Atkinson (1989) derived a series of regression parameters for NAFO Divisions $2 \mathrm{H}, 2 \mathrm{~J}, 3 \mathrm{~K}$, and NAFO Subareas $0+1$. Bergstad (1990) presented a number of different length-weight equations developed at different times of the year, and for males, females, and both sexes combined. For this work we used Bergstad's equation derived for the combined sexes in autumn.

Apart from the presently reported study two others, Jørgensen (1996) and Danke (1987) measured the fish to PAFL. Kelly et al. (1997) and Bergstad (1990) measured the PA. Atkinson (1981) notes however, that because roundnose grenadier are usually caught at depths greater than $400 \mathrm{~m}$ distortion in the region of the anus is common when they are brought to the surface, owing to both expansion of air in the bladder and extrusion of the intestines through the anus. Magnusson (1987) notes that Iceland has been using pre-anal fin length since 1978. Atkinson $(1981,1989)$ and Savvatimsky (1985) both mention that this measurement was adopted as a standard by NAFO in 1980.

In this work Kelly's (1997) and Bergstad's (1990) PA data were converted to PAFL using an equation developed by Atkinson in (1981) for fish in NAFO waters, PAFL = $1.063 \times$ PA- 0.38 . This equation agrees very well with one developed by the Marine Institute during this study, PAFL $=1.086 \times \mathrm{PA}-0.067$ (Table 2). At $26 \mathrm{~cm}$ PAFL, which is the largest fish measured on the Irish surveys, there is a difference of only $0.6 \mathrm{~cm}$ between the calculations.

Bergstad (1990) notes that fish from the Skagerrak are increasingly lighter at a given length compared with fish from all other areas, however Danke's (1987) equation for female Coryphaenoides rupestris from the mid-Atlantic ridge gives lighter values than the Skagerrak. Length-weight values for Greenlandic fish (Jørgensen 1996), male fish from the mid-Atlantic ridge (Danke 1987), and fish from this study appear very similar. Kelly's work from the Rockall Trough from the mid 1990s, which took place before the targeted fishery commenced to the west of Ireland, would indicate that fish were heavier than those caught during

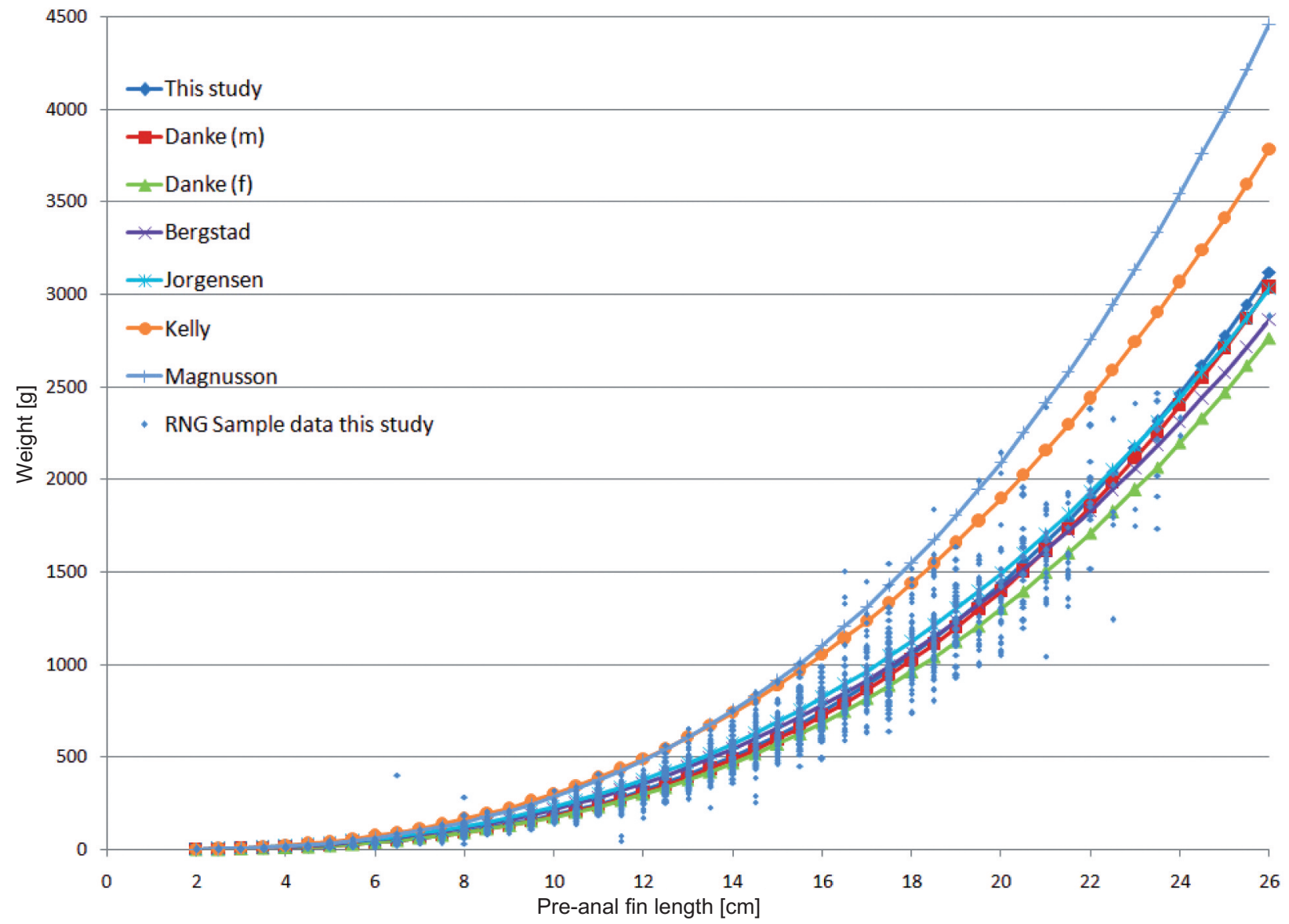

Fig. 3. Comparison of the Pre-anal fin length-weight relations developed for Coryphaenoides rupestris for different areas of its north Atlantic range 
the presently reported study. Kelly's (1997) regression is closely aligned with that from Icelandic waters up to a fish length of $14 \mathrm{~cm}$ PAFL (after Magnusson 1987). Magnusson's regression would indicate that Icelandic fish were much heavier for a given length than any other area. There is no obvious length-weight gradient across the Atlantic. Atkinson (1989) derived length weight equations for NAFO areas $0+1$ and $2+3$ and found significant differences between them, with fish from Subareas $0+1$ being lighter at length than those in Subareas $2+3$. Having compared his equations with those of Danke (1987) he concluded that the weight-at-length in Subareas $0+1$ is similar to those on the mid-Atlantic ridge, and comparisons with Magnusson (1987) and Gordon (1978) suggested that weight-at-length in Subareas $2+3$ is similar to that off Iceland and Scotland.

Danke's (1987) work from the mid-Atlantic ridge, corroborated by Jørgensen's (1996) work to the west of Greenland, indicated that male fish are heavier than females at larger sizes. The recent Irish data however, has shown that to the west of Ireland, females are slightly heavier than males at a comparable size, which corresponds with Bergstad's (1990) findings for the Skagerrak. Kelly (1997) noted that the asymptotic weight of females was substantially greater than that of males.

Trachyrincus murrayi Günther, 1887

Jørgensen (1996) recorded PAFL for T. murrayi ranging from $7.0 \mathrm{~cm}$ to $25.0 \mathrm{~cm}$, with the majority of fish around 15.0-21.0 $\mathrm{cm}$ and a primary mode at 19.0-20.0 $\mathrm{cm}$. In this study two relations are presented. The first is for small fish collected at $1000 \mathrm{~m}$ in area 2 in 2006, the second is for larger fish collected at $1500 \mathrm{~m}$ in area 5 in 2009. Lengths in the first group ranged from $3.8 \mathrm{~cm}$ to $7.7 \mathrm{~cm}$ with a modal length of $6.5 \mathrm{~cm}$. In the 2009 group lengths ranged from 11.9 to $19.1 \mathrm{~cm}$ with the majority of fish between 14.0 and $17.5 \mathrm{~cm}$, and a mode of $14.5 \mathrm{~cm}$. PAFL to weight and PAFL to TL relations derived from this study are given in Tables 1 and 2, respectively.

Jørgensen (1996) also produced a relation between PAFL and TL for T. murrayi. His sample size was 122 and his $r^{2}$, at 0.98 , is higher than from the current Irish data. The Irish data was collected from two distinct size classes. The smaller, a sample of 30 fish, ranged in size from 3.8 to $7.7 \mathrm{~cm}$, while the larger, 111 fish, ranged from 11.9 to $19.1 \mathrm{~cm}$. $r^{2}$ for both groups were 0.82 and 0.87 , respectively (Table 2). Coryphaenoides guentheri (Vaillant, 1888)

On the Irish surveys $C$. guentheri were caught between 1500 and $1800 \mathrm{~m}$ in all areas but they accounted for only $3.5 \%$ of the grenadiers caught. Between 2006 and 2007 a total of 73 C. guentheri samples were selected and taken back to the laboratory for length and weight measurements. The PAFL to weight relation is given in Table 1.

Jørgensen (1996) produced regressions to calculate weight from PAFL (Table 1), and TL from PAFL (Table 2). A comparison of the data from this study compared to Jørgensen's (1996) first equation would indicate that fish to the west of Greenland are heavier at a given size than those to the west of Ireland.
Jørgensen (1996) recorded lengths ranging from 2.0 to $14.5 \mathrm{~cm}$, which were dominated by one clear mode between 5.0 and $7.0 \mathrm{~cm}$ pre-anal fin length. Lengths in the current Irish survey ranged from 2.0 to $17.0 \mathrm{~cm}$ pre-anal fin length. The distribution peak in the Irish data however, was at $9.5 \mathrm{~cm}$.

\section{Coryphaenoides mediterraneus (Giglioli, 1893)}

On the Irish surveys $C$. mediterraneus were caught in low numbers between 1500 and $1800 \mathrm{~m}$, in all areas. It was the least common of all the main grenadier species. The PAFL-weight relation is given in Table 1.

\section{Coelorinchus caelorhincus (Risso, 1810)}

On the Irish surveys this species was primarily caught between 500 and $750 \mathrm{~m}$ and accounted for almost $10 \%$ of the grenadier catches. PAFL and weight measurements were carried out on 40 fish collected in 2006 (Table 1). Labropoulou and Papaconstantinou (2000) produced a PAFL to weight relation for the Ionian Sea. Analysis of the regressions would indicate that fish to the west of Ireland are heavier, at a given length, than those in the Ionian Sea. PAFL and TL measurements were carried out on a separate sample of 31 fish (Table 2). Also shown is a PAFL to TL relation for the Gulf of Cadiz (Gil et al. 2008). Coelorinchus labiatus (Köhler, 1896)

Catches from the Irish survey occurred between 1000 $\mathrm{m}$ and $1800 \mathrm{~m}$, in all areas, with the largest catches occurring at $1500 \mathrm{~m}$. They accounted for $5 \%$ of the grenadier catch. One hundred and twenty-five fish, collected in 2006, were measured for length and weight. The PAFL-weight relation is given in Table 1.

\section{Nezumia aequalis (Günther 1878)}

As well as being the second most numerous grenadier $N$. aequalis was the second most numerous species caught on the surveys. All the Irish catches took place between 750 and $1000 \mathrm{~m}$, with the highest catches taking place at $1000 \mathrm{~m}$. PAFL to weight measurements were made on a number of fish during the 2006 survey. On the 2009 survey fish were collected and returned to the laboratory for measurement. Again, owing to the fragile nature of the tail it was not possible to make PAFL to TL comparisons.

PAFL to weight measurements were made on 220 fish. Fifty fish were measured fresh in 2006 and 170 were frozen in 2009. Regressions were calculated for both groups (Table 1). All fish were collected at $750 \mathrm{~m}$, from Area 4 in 2006 and Area 5 in 2009. ANCOVA of the regressions of weight against length for fresh and frozen samples indicates that length was significantly linked to weight $\left(F_{1,216}=893.5, P<0.0001\right)$ and that while the slopes of the regressions do not differ $\left(F_{1,216}=0.554\right.$, $P>0.05)$, the effect of freezing was significant $\left(F_{1,216}=21.596\right.$, $P<0.0001)$, with frozen samples generally weighing $4.57 \mathrm{~g}$ more than fresh samples.

\section{Conclusion}

PAFL to weight relations are presented for seven species of grenadiers. The regression equation presented from this work for Coryphaenoides rupestris is comparable with a number of previously published studies for this 
species for the North Atlantic. Data on C. guentheri from this study compared to previously published data would indicate that fish from Greenlandic waters are heavier at a given size than those to the west of Ireland. PAFL-TL conversion factors are presented for two species where we consider tail breakage not to be an issue.

$\mathrm{TL}$ is an inappropriate measurement for many grenadier species owing to the illustrated problems of tailbreakage. Conversion equations provided in this and earlier papers help facilitate comparisons, but the common use of PAFL is advisable.

PAFL has been used by many scientists since the 1980s, however other measurements such as TL, HL, or PA have also been used. In addition, measurements of grenadiers have been rounded to the nearest $0.5 \mathrm{~cm}$, but also to the nearest centimetre or the nearest centimetre below, an important distinction. Only by applying the same measurement system, and the same measurement resolution, can biological variability in populations be detected. We re-iterate therefore the importance of measuring grenadiers using PAFL, to the nearest half centimetre below.

\section{REFERENCES}

Anonymous 2008. Report of the Planning Group on the Northeast Atlantic Continental Slope Survey (PGNEACS), 29 January-1 February 2008, Galway, Ireland. ICES CM 2008/LRC:02.

Anonymous 2009. Report of the Planning Group on the Northeast Atlantic Continental Slope Survey (PGNEACS), 9-11 June 2009, Tromsø, Norway. ICES CM 2009/LRC:03.

Anonymous 2012. Manual for the international bottom trawl surveys Series of ICES survey protocols. SISP 1-IBTS VIII.

Atkinson D.B. 1981. Partial length as a replacement for total length in measuring grenadiers. Journal of Northwest Atlantic Fishery Science 2: 53-56.

Atkinson D.B. 1989. Weight-length relationships of roundnose grenadier (Coryphaenoides rupestris Gunn.) in different areas of the north Atlantic. Fisheries Research 7 (1-2): $65-72$.

Atkinson D.B. 1991. Relationships between pre-anal fin length and total length of roughhead grenadier (Macrourus berglax Lacépède) in the Northwest Atlantic. Journal of Northwest Atlantic Fishery Science 11: 7-9.

Bajdalinov A.P., Dorovskikh R.S., Stulova L.I. 1986. On the transition to a new system of measurement of the North Atlantic roundnose grenadier (Coryphaenoides rupestris) length. NAFO SCR Doc. No. 86/61, Serial No. 1178.

Belsley D.A., Kuh E., Welsch R.E. 1980. Regression diagnostics: Identifying influential data and sources of collinearity. Wiley Series in Probability and Statistics. John Wiley and Sons, New York, NY, USA. DOI: 10.1002/0471725153

Bergstad O.A. 1990. Distribution, population structure, growth and reproduction of the roundnose grenadier
Coryphaenoides rupestris (Pisces: Macrouridae) in the deep waters of the Skagerrak. Marine Biology 107 (1): 25-39. DOI: 10.1007/BF01313239

Coggan R.A., Gordon J.D.M., Merrett N.R. 1999. Aspects of the biology of Nezumia aequalis from the continental slope west of the British Isles. Journal of Fish Biology 54 (1): 152-170. DOI: 10.1111/j.1095-8649.1999.tb00619.x

Danke L. 1987. Some particularities of roundnose grenadier (Coryphaenoides rupestris Gunn.) in the North Mid-Atlantic Ridge region. NAFO SCR Doc. No. 87, Serial No. 1378.

Froese R. 2006. Cube law, condition factor and weight-length relationships: history, meta-analysis and recommendations. Journal of Applied Ichthyology 22 (4): 241-253. DOI: 10.1111/j.1439-0426.2006.00805.x

Froese R., Tsikliras A.C., Stergiou K.I. 2011. Editorial note on weight-length relations of fishes. Acta Ichthyologica et Piscatoria 41 (4): 261-263. DOI: 10.3750/AIP2011.41.4.01

Gil J., Canoura J., Vila Y., Sobrino I. 2008. Information about grenadiers from bottom trawl surveys in the Gulf of Cadiz. American Fisheries Society Symposium 63: 49-64.

Gordon J.D.M. 1978. Some notes on the biology of the roundnose grenadier Coryphaenoides rupestris to the West of Scotland. ICES C.M. Doc. No. G: 40.

Jørgensen O.A. 1996. Distribution and biology of grenadiers (Macrouridae) in West Greenland waters. Journal of Northwest Atlantic Fishery Science 18: 7-29.

Kelly C.J., Connolly P.L., Bracken J.J. 1997. Age estimation, growth, maturity and distribution of the roundnose grenadier from the Rockall Trough. Journal of Fish Biology 50 (1): 1-17. DOI: 10.1111/j.1095-8649.1997.tb01336.x

Labropoulou M., Papaconstantinou C. 2000. Comparison of otolith growth and somatic growth in two macrourid fishes. Fisheries Research 46 (1-3): 177-188. DOI: 10.1016/ S0165-7836(00)00144-2

Magnusson J.V. 1987. Grenadier fish in Icelandic waters. NAFO SCR Doc. No. 87/87, Serial No. 1341.

Savvatimsky P.I. 1985. On correlation between total length and preanal length of roundnose grenadier in the north Atlantic. NAFO Scientific Council Studies 8: 61-65.

Savvatimsky P.I. 1994. Age structure of roughhead grenadier (Macrourus berglax) in the Northwest Atlantic, 1985. NAFO Scientific Council Studies 20: 53-64.

Swan S.C., Gordon J.D.M., Morales-Nin B., Shimmield T., Sawyer T., Geffen A.J. 2003. Otolith microchemistry of Nezumia aequalis (Pisces: Macrouridae) from widely different habitats in the Atlantic and Mediterranean. Journal of the Marine Biological Association of the UK 83 (4): 883-886. DOI: $10.1017 / \mathrm{S} 0025315403007987 \mathrm{~h}$

Received: 19 April 2013

Accepted: 24 September 2013

Published electronically: 31 December 2013 